\title{
DETECTION OF COASTAL DYNAMICS DEPENDING ON THE CASPIAN SEA LEVEL CHANGE USING REMOTE SENSING DATA: A CASE STUDY IN THE KURA GEOMORPHOLOGICAL SUB-REGION (AZERBAIJAN)
}

\author{
Jeyhun Yashar oglu GASIMOV
}

Institute of Geography named after acad. H.A. Aliyev, Azerbaijan National Academy of Sciences, Baku, Azerbaijan

*Corresponding author's e-mail: jeyhungasimov@mail.ru

\begin{tabular}{|c|c|}
\hline ARTICLE INFO & ABSTRACT \\
\hline Article history: & \multirow{6}{*}{$\begin{array}{l}\text { Based on the analysis performed in the Kura geomorphological sub-region of the Caspian coastal } \\
\text { zone, it was determined that the sea level rise of } 2.43 \mathrm{~m} \text { in } 1976-1996 \text { caused an average annual } \\
\text { rate of erosion processes about } 75 \text { times higher than accumulation processes. In 1996-2019, the } \\
\text { stabilization and the following drop of the sea level of } 1.39 \mathrm{~m} \text { led to an average annual rate of } \\
\text { accumulation processes up to } 14 \text { times higher than the average annual rate of erosion processes. } \\
\text { This pattern is observed along the entire coastline of those periods. Erosion processes in the initial } \\
\text { stage (1976-1996) increased the indentation and length of the coastline by almost } 2 \text { times, and in } \\
\text { the next stage (1996-2019) the intensification of accumulation processes resulted in the smoothing } \\
\text { and reduction of the coastline by } 35 \% \text {. } \\
\text { Statistical analysis of coastlines was carried out by processing Landsat satellite images for 1976- } \\
\text { 2019; each coastline was divided into } 14 \text { segments according to geomorphological zones and their } \\
\text { morphostructures in the study area. The development forecast for the next } 10 \text { and } 20 \text { years is } \\
\text { provided. }\end{array}$} \\
\hline $\begin{array}{l}\text { Received } 13 \text { April } 2021 \\
\text { Accepted } 18 \text { September } 2021 \\
\text { Available online } 4 \text { October } 2021\end{array}$ & \\
\hline Keywords: & \\
\hline $\begin{array}{l}\text { Shoreline } \\
\text { Abrasion }\end{array}$ & \\
\hline Accumulation & \\
\hline $\begin{array}{l}\text { NDWI } \\
\text { change detection } \\
\text { DSAS }\end{array}$ & \\
\hline
\end{tabular}

\section{INTRODUCTION}

Being located at the physical contact of land and water basin (Fu et al., 2017; Alicandro et al, 2019; Pugliano et al., 2019; Liu, 2017; Appeaning et al., 2008), coastal zones are natural territories with a complex geological-geomorphological structure, unique ecological environment, biological diversity and climatic conditions (Ashis, 2002; Zollini et al., 2020). In recent times, coastal areas have become vulnerable to the effects of natural disasters (typhoons, tornadoes, tsunamis, abrasions, floods, etc.) and anthropogenic impacts (deforestation of coastal zones, exploitation of sediments at the mouth of rivers, construction of coastal dams and breakwaters, etc.) and are home to more than $45 \%$ of the world's population with increasing density (Mubarak, 2018; Dominici, 2020; Jackson et al., 2013; Nunes, 2009; Komar, 2010).

One of the characteristic features of the Caspian Sea (392.6 thousand sq. km), the largest closed water body on Earth, is the periodic change of its level in time and space, which affects the environment, especially the natural and anthropogenic ecosystems of the littoral zone to some extent. The sea level change of the Caspian Sea is influenced by geologicalgeomorphological (fluviodynamic activity, seismic and recent tectonic movements, sediment accumulation, mud volcanism), hydroclimate (humidification, evaporation, waterlogging of rivers), anthropogenic (irrigation and reservoirs), and spacerelated factors (solar activity). The above-mentioned factors contribute to the fluctuation of the sea level and the water balance of the Caspian Sea as follows: a) the solar activity, contributing to the formation of atmospheric circulation; b) the atmospheric circulation, contributing to the humidification regime; c) the natural humidification regime, such as precipitation on the sea surface, controlling the evaporation from the sea surface; d) the water flowing to the sea by up to 130 rivers (Shirinov et al., 1998), forming $80 \%$ of the water balance; e) the anthropogenic factors, related to human economic activity, such as water taken from the sea and rivers flowing into it. Along with the changes in water balance, changes in the seabed relief and the size of the seabed in general have some effects on the sea level fluctuations of the Caspian Sea. The sea pit and its relief change under the influence of geological processes, such as the violation of the compensation between the new tectonic subsidence and sedimentation processes, the breccia masses rising to the seabed due to the eruption of underwater mud volcanoes, etc. (Shirinov et al., 1998, Mammadov, 2007). 


\section{STUDY AREA}

Caspian Sea coasts are divided into 3 regions: Azerbaijan-Iran-Turkmenistan (collision orogenic zone), North Caspian (Epiplatform depression coasts region), and Ustyurt (platform depression zone). The Azerbaijan-Iran-Turkmenistan region corresponds to the Caucasus-Transcaspian stable platform zone and includes the coasts of Dagestan, Azerbaijan, Iran, and Turkmenistan (from the mouth of the Terek River to the city of Turkmenbashy); it is characterised by the most mobile (active), highly contrasting new and recent tectonic movements. Abrasion, accumulative, accumulative-delta, accumulative lagoon coasts have been developed within the region. The regular distribution of these coastal types in the territory allows the separation of 10 sub-regions (Fig. 1). These are Terek-Sulak, Dagestan, Samur-Davachi, GilaziYashma, Absheron, Gobustan, Kura, Lankaran, Iran, and Turkmenistan sub-regions (Shirinov et al., 1998).

The Kura geomorphological coastal sub-region geologically corresponds to the upland depression of the same name. In the new tectonic stage, the depression was subjected to an absolute tectonic subsidence (1400-1600 m), which is compensated by the accumulation of sediment. In recent times, the depression hereditarily descends along with the coasts. Therefore, in the sub-region, there are only accumulative processes and corresponding plains, in some places complicated by mud volcano morphostructures (Hamamdagh on Pirsaat cape, mud volcano of the same name on Bandovan cape, Dovshanli mud volcanoes) and accumulative relief forms with relative heights up to several meters (coastal sand swells, dunes, etc.). Abrasion processes are not typical for these coasts. They are observed only during periods of sharp changes in the sea level due to sharp changes in the indentation-bench coefficient, slope, and the balance of sedimentation and they are temporary phenomena. Lagoons and swamps are spread over the most tectonic subsided coasts. The underwater slope is also flat. Intermittent mud volcanoes and underwater deltas are found (Leontiev and Khalilov, 1965, Shirinov et al., 1998).

Despite its uniformity compared to other coasts of Azerbaijan, the Kura geomorphological coastal sub-region is divided into 3 zones due to the diversity of geomorphologic processes (Fig. 1): Shirvan zone, consisting of abrasion-accumulative and accumulative alluvial and alluvial-sea plains, covering the coasts of the South-Eastern Shirvan plain, the Kura delta zone, corresponding to the Kura delta, which began to form in the late 18th century, and the Gizilagaj zone, which corresponds to the part of the Kura basin that has undergone the most tectonic subsidence processes (Shirinov et al., 1998).

\section{MATERIALS AND METHODS}

Analysis, mapping, monitoring, and forecasting of coastline changes by field measurements and aerospace methods are important for integrated coastal zone management and planning, resource management, environmental research, and sustainable development (Aryastana et al., 2018; Hashmi and Ahmad, 2018). Application of Geographic Information Systems and statistical algorithms, implemented in GIS environment, and remote sensing (space images with different resolutions, unmanned aerial vehicle images, etc.) for detailed analysis of short and long-term changes in coastline dynamics, provide ample opportunities for forecasting and cartographic description of coastline changes, based on established models (Hashmi and Ahmad, 2018; Dominici, 2020).

In this study the following multispectral images were processed: Landsat 2 MSS (1976) with a resolution of $60 \mathrm{~m}$ belonging to column 179 and rows 32-33 of the World Reference System on the Landsat satellite, Landsat 5 MSS (1987) with a resolution of $60 \mathrm{~m}$ belonging to column 167 and rows 32-33; Landsat 5 TM (1996, 1997, 1998, 2005, 2007) with a resolution of $30 \mathrm{~m}$; Landsat 8 OLI \& TIRS (2017, 2019). The dynamics of erosion and accumulation processes over 43 years, caused by fluctuations of the Caspian Sea level (rise, stabilization, and drop), were analyzed in the Kura geomorphological sub-region. The NDWI (Normalized Difference Water Index) index was constructed in ArcGIS 10.8, using satellite images recorded in green and near-infrared (NIR) channels, and thus the land and water areas of the study area were automatically classified:

NDWI $=($ Green + NIR $) /($ Green - NIR $)$

Using the change detection function (Confusion Matrix - Two Grids) of the SAGA GIS 7.5 software, the change and transformation of land and water areas were determined at the date of the satellite imagery. Confusion Matrix tool compares two classified grids, creates a confusion matrix and derives coefficients as well as the combinations of both classifications as a new grid. Also, at the date of satellite imagery, the coastline of the Kura geomorphological sub-region was extracted by vectorization of NDWI raster layers.

The dynamics of coastal processes (abrasion and accumulation) were determined in the study area, based on the modeling of the coastline for 1976, 1987, 1996, 1997, 1998, 2005, 2007, 2017, 2019 using the DSAS v.5 (Digital Shoreline Analyze System) tool operating on the ArcGIS 10.8 platform. This tool requires shorelines (coastlines of different years) in a single feature class and baseline, located offshore, divided into 14 groups (segments) in our case. These data are stored in a personal geodatabase in meter units in a projected coordinate system (WGS 1984 UTM Zone 39N) in ArcGIS 10.8 software. Then, transects were generated, intersecting baseline and shorelines with $50 \mathrm{~m}$ interval to create a measurement points which were used to calculate shoreline change rates. Shoreline change rates, such as Shoreline Change Envelope (SCE), the final shoreline movement at the 


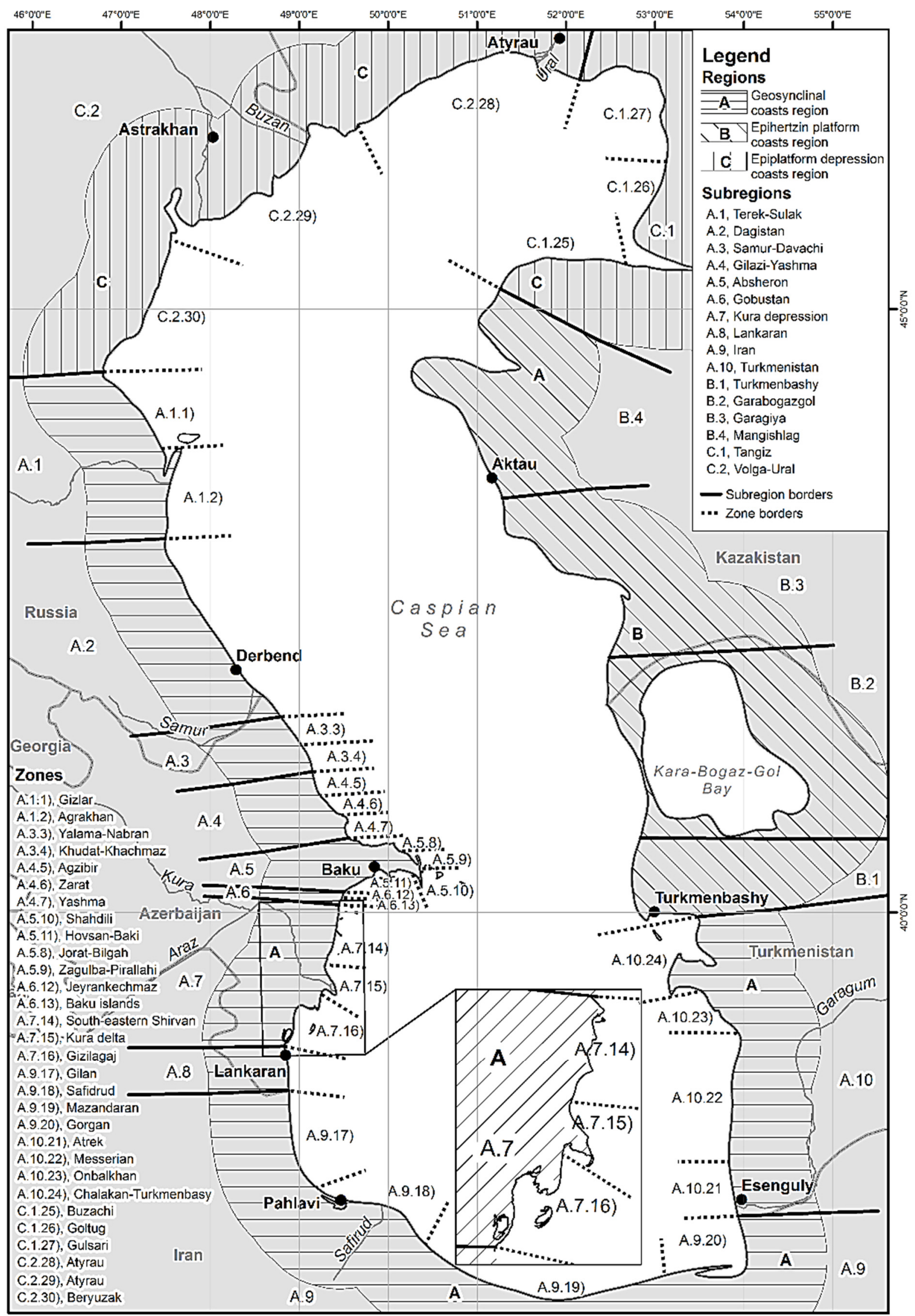

Fig. 1 Geomorphological zoning scheme of the Caspian Sea coasts (Shirinov et al., 1998). 
earliest and most recent dates (NSM - Net Shoreline Movement), the final shoreline movement, and its ratio to the recorded time interval (EPR - End Point Rate) were calculated by using the distances between the reference baseline and each shoreline intersection along a transect. At the final stage 10- and 20-year forecasts were calculated based on the datum of the input shoreline data, estimating the shoreline position and rate every 10th of a year. This calculation is done by using the Kalman filter (1960) to combine observed shoreline positions with model-derived positions to forecast a future shoreline position (Kalman, 1960; Long and Plant, 2012; Himmelstoss et al., 2018).

\section{ANALYSIS AND RESULTS}

The level fluctuations of the Caspian Sea, a closed basin with its own sea-level regime, are manifested in geological-historical (centennialmillennial and glacial-interglacial) and recent (tidal, seasonal, decadal) time scales (Kroonenberg, 2012). Level changes in the geological-historical period are mainly associated with global climate change, as well as the geological development of the area. Such a change in sea level, measured at 10-100 meters, resulted in transgressions and regressions that span tens of thousands of years (Shirinov et al., 1998). During a considerable part of the Pleistocene, the Caspian Sea, as the relict of East Parathetis ocean, was a closing basin with sharp sea-level fluctuations, represented by the periodical transgressions and regressions $( \pm 50 \mathrm{~m})$ (Svitoch, 2012). Investigation of deltas and terraces adjacent to the Caspian Sea has indicated that the pattern of Holocene fluctuations, varied between 20 and $32 \mathrm{~m}$ below recent sea-level. Six transgressive episodes are recognized in the Holocene record, separated by regressive episodes when the level dropped below $-28 \mathrm{~m}$ above sea level (Rychagov, 1997). The sharp fluctuations of the Caspian Sea in recent times are observed about every 50 years and its value reaches $-2.0^{-}-2.5$ meters. Seasonal changes in the level of the Caspian Sea, ranging from $30-40 \mathrm{~cm}$, are also observed when the level reaches its highest value in June-August and the lowest value in December-February (Shirinov et al., 1998).
Systematic instrumental observations on the level of the Caspian Sea began in 1830 (by academician J. Lents) and continue until today. Based on the statistical analysis of the actual data obtained, a certain periodic regularity was found in the sea level fluctuations. In 1830-1929, the level is divided into 12 periods of 2-8 years of movement ( 6 rises and 6 drops) and 5 periods of relative stability of $8-13$ years. During this period (1830-1929) the level of the Caspian Sea fluctuated in the range of $1 \mathrm{~m}$ around the absolute height of $-26 \mathrm{~m}$, the average multi-year value was $-25.83 \mathrm{~m}$. Later, when the level fluctuated, the duration of the periods changed significantly. In 1929-1941 (12-year period), the level dropped by $1.84 \mathrm{~m}$ at an average rate of $15.3 \mathrm{~cm}$ per year. The level of the Caspian Sea fluctuated around $-29 \mathrm{~m}$, in 1941-1977 (37 years of relative stability) with small oscillations (short-term rises in 1946-1948 and 1956-1958). In 1940-1956, the level of the Caspian Sea fell by $2.5 \mathrm{~m}$ compared to 1929 , and in the $1960 \mathrm{~s}$ it was stabilized around the absolute height of $-28.4 \mathrm{~m}$. Between 1970 and 1977, there was another sharp drop in level. The level of the Caspian Sea reached the lowest value of $-29.02 \mathrm{~m}$ recorded in the last 200 years and dropped by $3.8 \mathrm{~m}$ since the beginning of instrumental observations. In 1977-1995 (18-year period), the level of the Caspian Sea began to rise sharply at an average rate of $14.5 \mathrm{~cm}$ per year (up to $30 \mathrm{~cm}$ in some years) and rose to a total of $2.38 \mathrm{~m}$ and reached $-26.5 \mathrm{~m}$ in 1995 (Figs. 2, 3). This is considered the most intensive and continuous rise during the instrumental observation period (Ignatov et al., 1993; Mammadov, 2014; Khalilov, 2010; Khalilov, 2020). Later, the level began to gradually decrease and stabilize, falling to $35 \mathrm{~cm}$, in 1996-2000.

The level of the Caspian Sea began to rise again in 2001 and rose to $30 \mathrm{~cm}$ during 2001-2005. In 20052015, the level of the Caspian Sea began to decrease again and in 2014 reached $-26.90 \mathrm{~m}$. The regular drop in sea level stopped in 2015 and the level began to stabilize. The level of the Caspian Sea began to drop again in 2018 to $-27.67 \mathrm{~m}$ and in 2019 to $-27.89 \mathrm{~m}$. According to Khalilov (2010), the periodic variability of the Caspian Sea level with different duration and

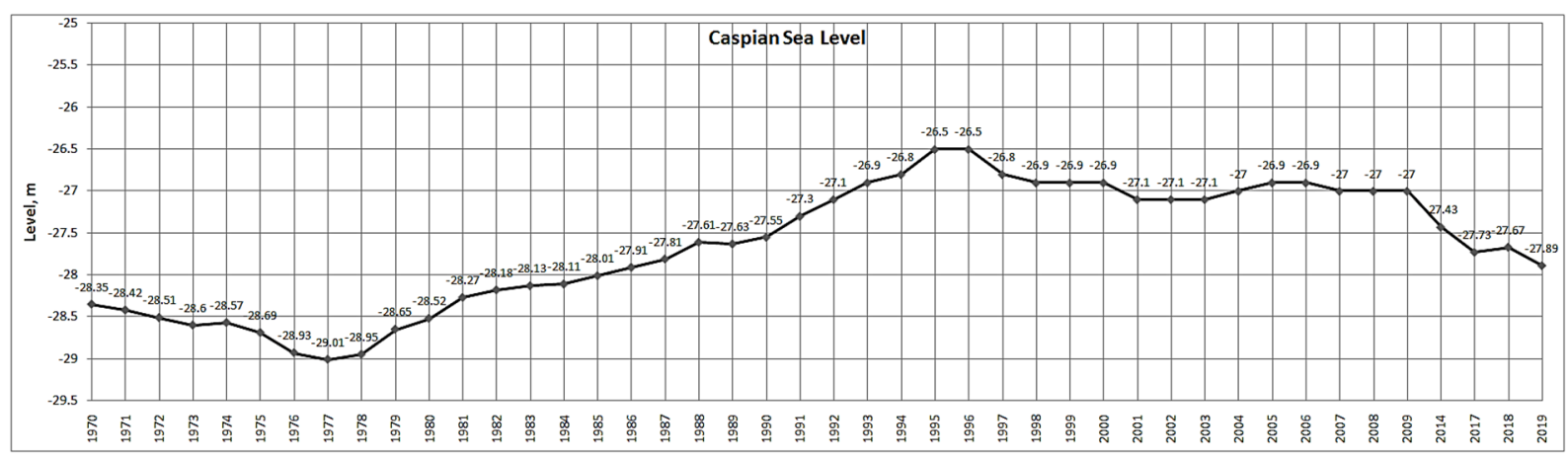

Fig. 2 The level of the Caspian Sea. 


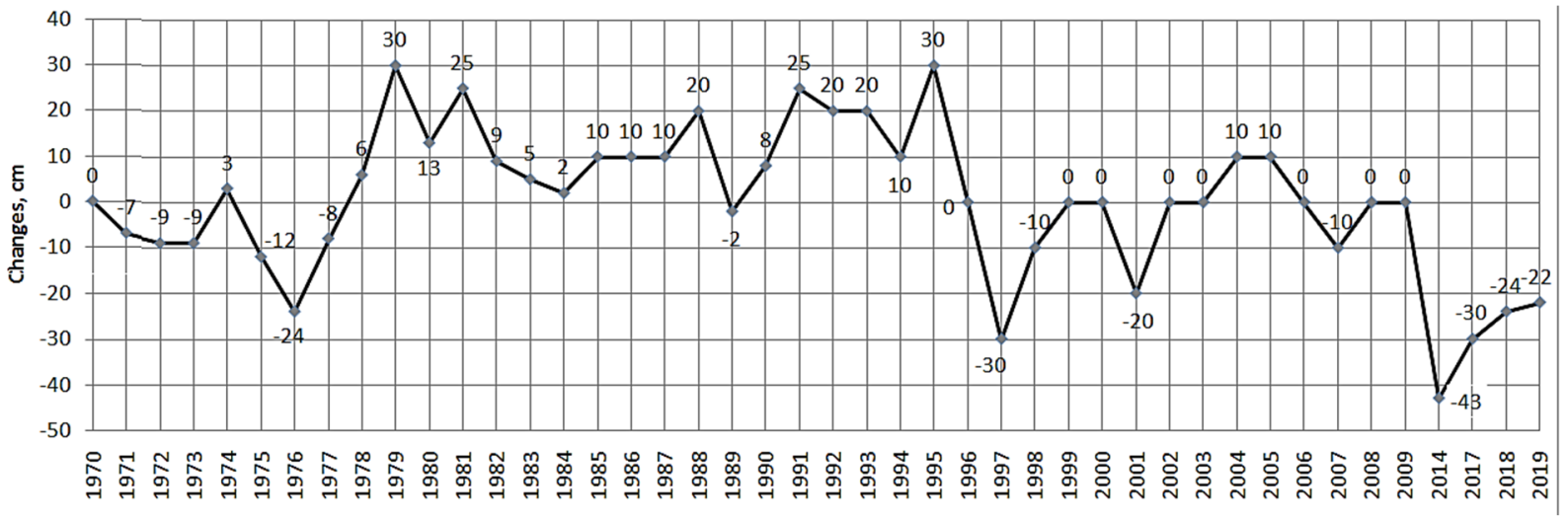

Fig. 3 Sea level change of the Caspian Sea.

Table 1 Dynamics of coastal processes in the Kura geomorphological sub-region.

\begin{tabular}{|c|c|c|c|c|c|}
\hline \multirow[t]{2}{*}{ Years } & \multicolumn{2}{|c|}{$\begin{array}{c}\text { Area indicators by years } \\
(\mathrm{sq} . \mathrm{km})\end{array}$} & \multirow[t]{2}{*}{$\begin{array}{l}\text { Time interval } \\
\text { (years) }\end{array}$} & \multicolumn{2}{|c|}{$\begin{array}{c}\text { Average annual indicator } \\
\text { (sq.km / year) }\end{array}$} \\
\hline & Accumulation & Abrasion & & Accumulation & Abrasion \\
\hline 1976-1987 & 27.479 & 193.793 & 11 & 2.498 & 17.618 \\
\hline $1987-1996$ & 0 & 197.905 & 9 & 0 & 21.989 \\
\hline 1976-1996 & 5.390 & 402.854 & 20 & 0.2695 & 20.143 \\
\hline 1996-1997 & 16.174 & 7.618 & 1 & 16.174 & 7.618 \\
\hline 1997-1998 & 13.95 & 3.072 & 1 & 13.95 & 3.072 \\
\hline $1998-2000$ & 10.511 & 140.88 & 2 & 5.2555 & 70.44 \\
\hline $2000-2005$ & 174.169 & 2.934 & 5 & 34.834 & 0.587 \\
\hline $2005-2007$ & 17.203 & 32.506 & 2 & 8.601 & 16.253 \\
\hline $2007-2017$ & 202.554 & 1.997 & 10 & 20.255 & 0.1997 \\
\hline 2017-2019 & 52.793 & 57.546 & 2 & 26.397 & 28.773 \\
\hline 1996-2019 & 305.678 & 22.562 & 23 & 13.29 & 0.981 \\
\hline
\end{tabular}

amplitude is constant and will be finished with the end of the collision of the Eurasian and Arabian lithosphere plates and the complete closure of the Tethys Ocean (Khalilov, 2010). However, several researchers (Mammadov and Humbatov, 1996; Mammadov et al., 1998) attribute the lowering to global climate change.

Compared to other geomorphological processes, rapid changes in coastal processes (coastal abrasion, development of dunes, etc.), under the influence of various factors, affect coastal areas, crops, beaches, social infrastructure, port economy, etc. and pose high geomorphological risk. The long-term geological evolution of the coast also plays an important role in sediment accumulation, tectonic processes, and sea level changes in the coastal zones. The combined use of geological, historical, and instrumental measurement data in the study of coastline development over short periods (decades to millennia) yields more effective results (Sanchez, 2010; Rio, 2009).

All coastal processes are mainly determined by abrasion and accumulation, primarily by fluctuations in sea level and the inclination of the bottom in the coastal zone. The rise in sea level results in the reconstruction of the underwater slope and washing of the shore at the level surface and the washing material is retreated towards the underwater coastal slope. It is estimated that a $3 \mathrm{~mm}$ rise in sea level causes the coastline to recede $1 \mathrm{~m}$. Abrasions are observed on deep shores, and accumulation processes are observed on shallow shores. The initial inclinations in the coastal zone are determined by the geological structure: in the areas where anticlinoriums appear on the coasts, the steep underwater slopes prevail, and in synclinoriums, on the contrary, smooth slopes prevail (Aseev, 1988). Thalassogenic processes in the form of abrasion (washing), accumulation, and flooding are widespread on the eastern coasts of the Kura Depression washed by the Caspian Sea (in the Kura geomorphological sub-region - from Alat Cape to the city of Liman). In this part, depending on the fluctuations of the sea level, both destructive (abrasion) and constructive (accumulation) processes occur (Shirinov, 1973).

Due to the rising of the Caspian Sea level (19781995), the abrasion process resulted in the retreat of the coastline and the washing of the land area by seawater, which caused serious damage to settlements, farms, and transport infrastructure located in the coastal zone. The process of abrasion in the area developed mainly in the caves corresponding to anticline folds, penetrated the sea (Pirsaat, Bandovan, etc.) and in areas where the sea rises to the ancient 


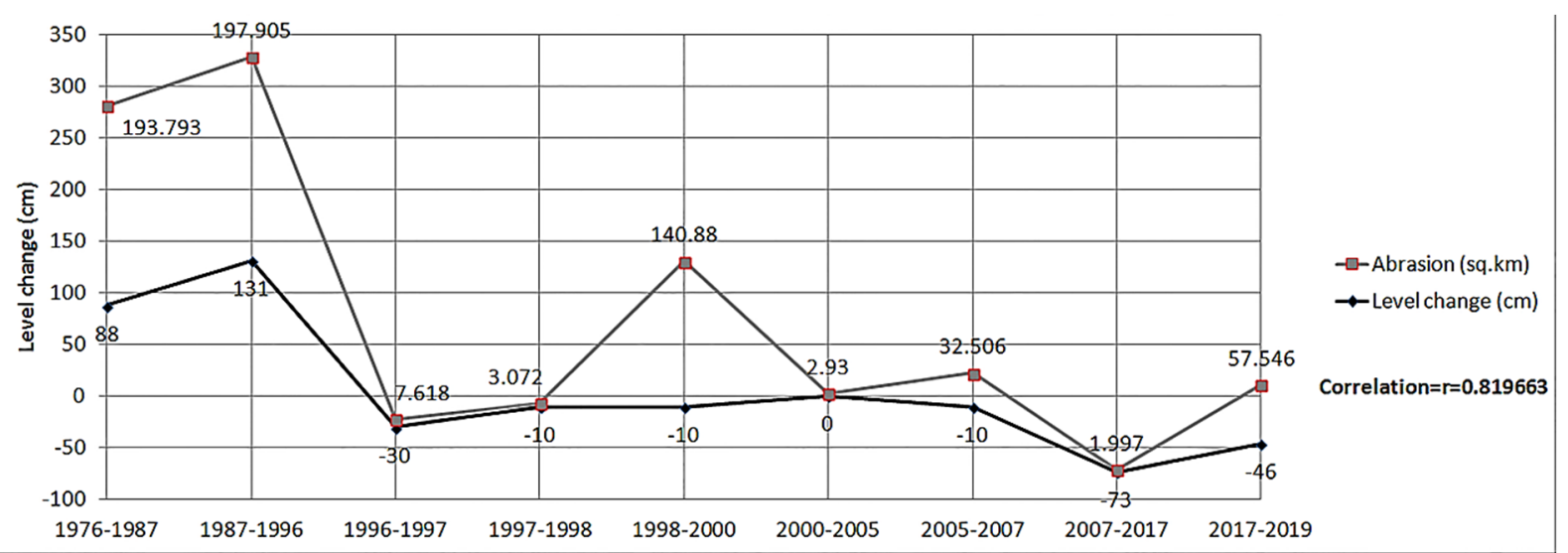

Fig. 4 Relationship between level fluctuations of the Caspian Sea and abrasion processes in the Kura geomorphological sub-region.

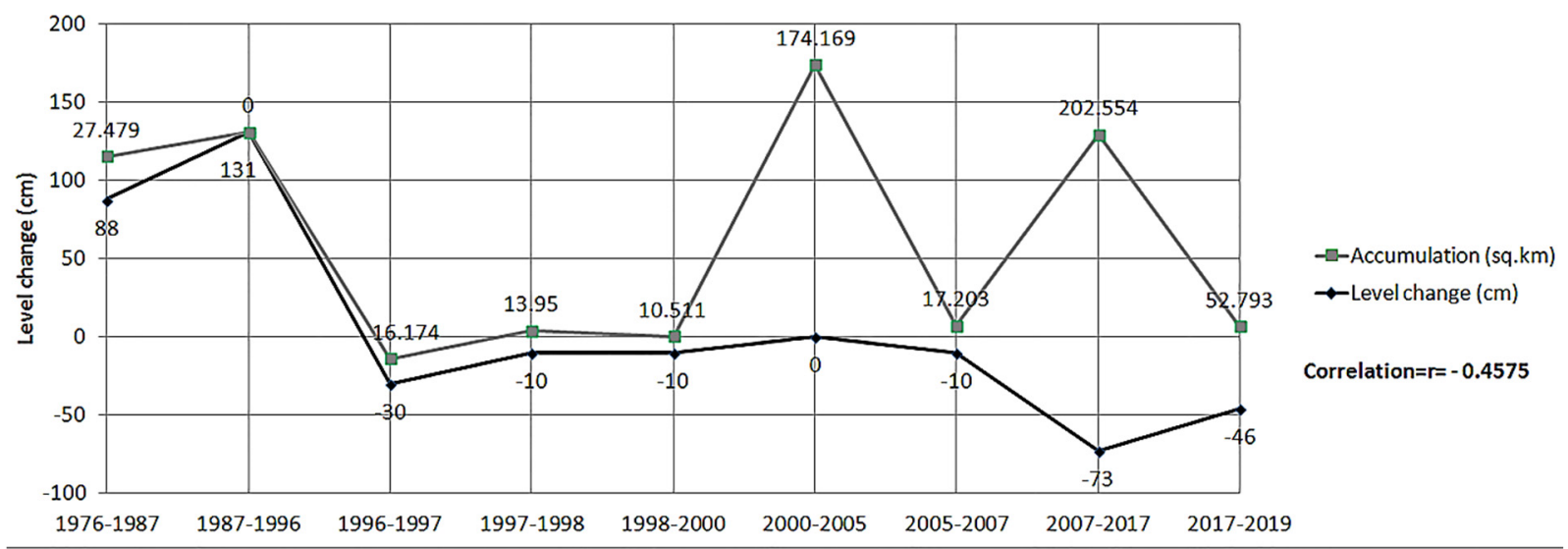

Fig. 5 Relationship between Caspian Sea level fluctuations and accumulation processes in the Kura geomorphological sub-region.

coastal uplands along the coast. The development of the process of abrasion in the cape is associated with the activity of tectonic structures complicated by mud volcanoes and their gradual rise (Shirinov, 1973).

As can be seen from the table (Table 1), the exposure of the coasts to abrasion and accumulation processes is in line with the sea level estimates of the Caspian Sea for the last 43 years. During 1976-1996, the level of the Caspian Sea rose from $-28.93 \mathrm{~m}$ to $-26.5 \mathrm{~m}(2.43 \mathrm{~m})$. Such an increase in level over 20 years, in turn, was accompanied by a sharp increase in the area of washed coasts in the Kura geomorphological sub-region, which also covered an area of 402,854 sq. km (Fig. 4).

The beginning of the lowering of the Caspian Sea level since 1996 has resulted in the development of accumulative processes in the Kura geomorphological sub-region (Fig. 5). During 1996-2005, the average annual growth rate of accumulative processes was more than 5 times the rate of abrasion processes. The short-term rise in the level of the Caspian Sea during 2001-2005 was accompanied by the development of abrasion processes. In 2005-2007, the coasts subjected to abrasion processes in the study area were about twice the area of accumulative coasts. The drop in sea levels since 2006 led to a reemergence of accumulative processes. During 10 years (2007-2017) the area of accumulative coasts increased to 202,554 sq. $\mathrm{km}$. Since 2015 , there has been a gradual stabilization at the level of the Caspian Sea, which in turn manifested itself in the balance of washing (flooding) and accumulation processes in the Kura geomorphological sub-region in 2017-2019. Thus, a slight difference $(4,753 \mathrm{sq}$. $\mathrm{km}, 8 \%)$ was observed between the washed $(57,546$ sq. $\mathrm{km})$ and accumulated $(52,793$ sq. $\mathrm{km})$ coastal areas. Most of the flooding was in 2017 due to the restoration of almost dry Lesser Gizilagaj Bay (54,221 sq. km).

In 1976-1987, due to the intensive rise of the Caspian Sea level, the coastline was extended to $0.8 \mathrm{~km}$ near Alat cape, $0.6 \mathrm{~km}$ near Pirsaat cape, $0.35 \mathrm{~km}$ near Bandovan cape, $4.5 \mathrm{~km}$ in the Kura delta region, $10 \mathrm{~km}$ in the Gizilagaj Bay region, $1.4 \mathrm{~km}$ in the territory of Liman city, $3 \mathrm{~km}$ in Kurdili and $1.2 \mathrm{~km}$ in the Sari Peninsula, in 1987-1996, the coastline was withdrawn to $0.7 \mathrm{~km}, 0.75 \mathrm{~km}, 0.3 \mathrm{~km}, 5 \mathrm{~km}, 13 \mathrm{~km}$, $0.5 \mathrm{~km}, 9 \mathrm{~km}$, and $2 \mathrm{~km}$, respectively. During this period, because of intensive abrasion and flooding 
processes, the Kurdili connection with the land was completely cut off.

The washing and flooding processes that occurred in the Kura geomorphological sub-region caused periodic damage to local infrastructure and farms, arable lands, and settlements. Sarigamysh, Dalgali (Prorva), Sahiloba (Saratovka), Mayak-1, Mayak-2, Subh villages of Neftchala region, Liman city, Shirvanli (Jarski), Kurdili, Narimanabad-2, Baligchilar, Uzumchuluk, Narimanabad-1 villages of Lankaran region were exposed to abrasion and flooding processes in the coastal areas. To prevent the washing of the coasts because of the abrasion process, it is important to protect the coasts using concrete pyramids, brick structures, and rocks and build wave breakers (Gasimov, 2014).

In the Kura geomorphological sub-region, marine accumulation processes are more widespread than abrasion processes. In the coastal zone, bottom inflows are accumulated along the coast and in the transverse direction. According to the change in wave energy consumption and velocity, larger deposits are collected in areas close to the water level (beaches, foothills), and as they move away from the shore (towards the submarine slope and beyond), the size of the deposits gradually decreases, that is to say, sorting occurs according to the shape, grain-size and mineralogical composition of the deposits (Aseev et al., 1988).

At the beginning of the 1970s, accumulative coasts accounted for $85.3 \%(270 \mathrm{~km})$ of the total coastal length $(340 \mathrm{~km})$ within the plain. From 1977 to 1996, due to the rise in the level of the Caspian Sea, the sea level in some accumulative coasts rose to the ancient coastal uplands, and accumulation processes in these areas replaced by abrasion (Shirinov, 1973). Due to this erosion, the length of the accumulative coasts decreased. The main reasons for the prevalence of accumulative coasts in depression are the following: due to the tectonic structure of the coastal zone they mainly correspond to recent sedimentation areas, the low underwater slope; the sedimentation of washed materials by coastal currents; the availability of terrigenous materials brought by rivers along with the Kura River; the presence of indented-protruding, plain and partially swampy areas in the southern part of the coastal zone, bringing large amounts of biogenic materials to the coastal zone (Shirinov, 1973).

The marine accumulation that develops in the area is divided into 3 types according to genetic characteristics: sea, delta, and lagoon. Marine (sea) accumulation is mainly within the South-Eastern Shirvan plain, in the wide bays between the Sangachal, Alat, Pirsaat, and Bandovan caves, as well as in the bays north and south of the Kura delta, on the coasts of Lankaran plain; delta accumulation is in the recent delta of the Kura River; lagoon type is observed in the distance of $130 \mathrm{~km}$ inside the Gizilagaj Bay, separated by Sara Island. Because of falling sea levels in the Bay (from 1929 to 1978, at intervals) and the shallowing of the Bay, the archipelago and the banks merged to form a large island (Sara Island) more than $50 \mathrm{~km}$ long. This island, which is connected to the mainland by a dam, separates the Gizilagaj Bay from the main part and creates the Lesser Gizilagaj Bay (Shirinov, 1973).

Due to the lowering of the Caspian Sea level and intensification of accumulation processes in 19962007, the coastline was extended to $0.2 \mathrm{~km}$ near Alat cape, $0.3 \mathrm{~km}$ near Pirsaat cape, $0.18 \mathrm{~km}$ near Bandovan cape, $1.9 \mathrm{~km}$ in the Kur delta region, $0.5 \mathrm{~km}$ in the Gizilagaj Bay region, $0.3 \mathrm{~km}$ near the Liman city, $1.9 \mathrm{~km}$ in the Kurdili and $0.2 \mathrm{~km}$ in the Sari Peninsula, in 2007-2019, the coastline extended to the sea up to $0.54 \mathrm{~km}, 0.9 \mathrm{~km}, 0.2 \mathrm{~km}, 6 \mathrm{~km}, 15 \mathrm{~km}$, $1.8 \mathrm{~km}, 5 \mathrm{~km}$, and $1.4 \mathrm{~km}$, respectively (Fig. 6).

Based on the analysis, it was determined that the total length of the coastline in the study area was $467.583 \mathrm{~km}$, in 1976, $662.880 \mathrm{~km}$, in 1987 , $863.495 \mathrm{~km}$, in $1996,803.982 \mathrm{~km}$, in 1997 , $791.619 \mathrm{~km}$, in $1998,806.177 \mathrm{~km}$, in 2000 , $827.13 \mathrm{~km}$, in $2005,863.957 \mathrm{~km}$, in 2007 , $571.958 \mathrm{~km}$, in $2017,638.497 \mathrm{~km}$, in 2019 . In 1976 1996, the length of the coastline increased from $467,583 \mathrm{~km}$ to $863,495 \mathrm{~km}(395,912 \mathrm{~km}$ more, $54 \%)$. During this period, the level of the Caspian Sea rose (up to $2.5 \mathrm{~m}$ ) and the coastline had been affected by abrasion. Reduction of coastline length from $863,495 \mathrm{~km}$ to $806,177 \mathrm{~km}(57,318 \mathrm{~km}$ less, $7 \%)$, in 1996-2000, was associated with flattening of shores under the influence of developing ac- cumulation processes as a result of stabilization and gradual lowering of the Caspian Sea level $(35 \mathrm{~cm})$ and a decrease in indentation and protrusions. The level of the Caspian Sea began to rise again in 2001, and the sea level rose to $30 \mathrm{~cm}$ during 2001-2005. In this regard, under the influence of abrasion processes, the increase in indentation on the coasts, as well as significant changes in the configuration of the shores of the Lesser Gizilagaj Bay due to natural (change of water surface area) and anthropogenic factors (discharge through a special canal) caused an increase in the length of the coastline - from $791,619 \mathrm{~km}$ to $863,957 \mathrm{~km}(72,338 \mathrm{~km}$ more, $8 \%)$ in 1998-2007. The decrease of the Caspian Sea level after 2005 and the development of re-accumulation processes on the coasts, the almost drying up of the Lesser Gizilagaj Bay, resulting in the decrease - from $863.957 \mathrm{~km}$ to $571.958 \mathrm{~km}(291,999 \mathrm{~km}, 66.202 \%)$, in 2007-2017. Stopping the lowering and stabilizing of the Caspian Sea level since 2015, the restoration of the Lesser Gizilagaj Bay increased the length of the coastline from $571,958 \mathrm{~km}$ to $638,497 \mathrm{~km}$, during $2017-2019$.

During the study, the coastline, which acts as the baseline of the Caspian Sea, was divided into 14 sections (segments) corresponding to the regions and morphostructure of the Kura geomorphological coastal sub-region (Fig. 8). The statistical indicators reflecting the dynamics were analyzed. Also, coastal lines projected for the next 10 (2031) and 20 (2041) years were drawn using the DSAS v.5 tools operating in ArcGIS 10.8 environment. Here, the distance between the coastline of 2019 and the coastline of 

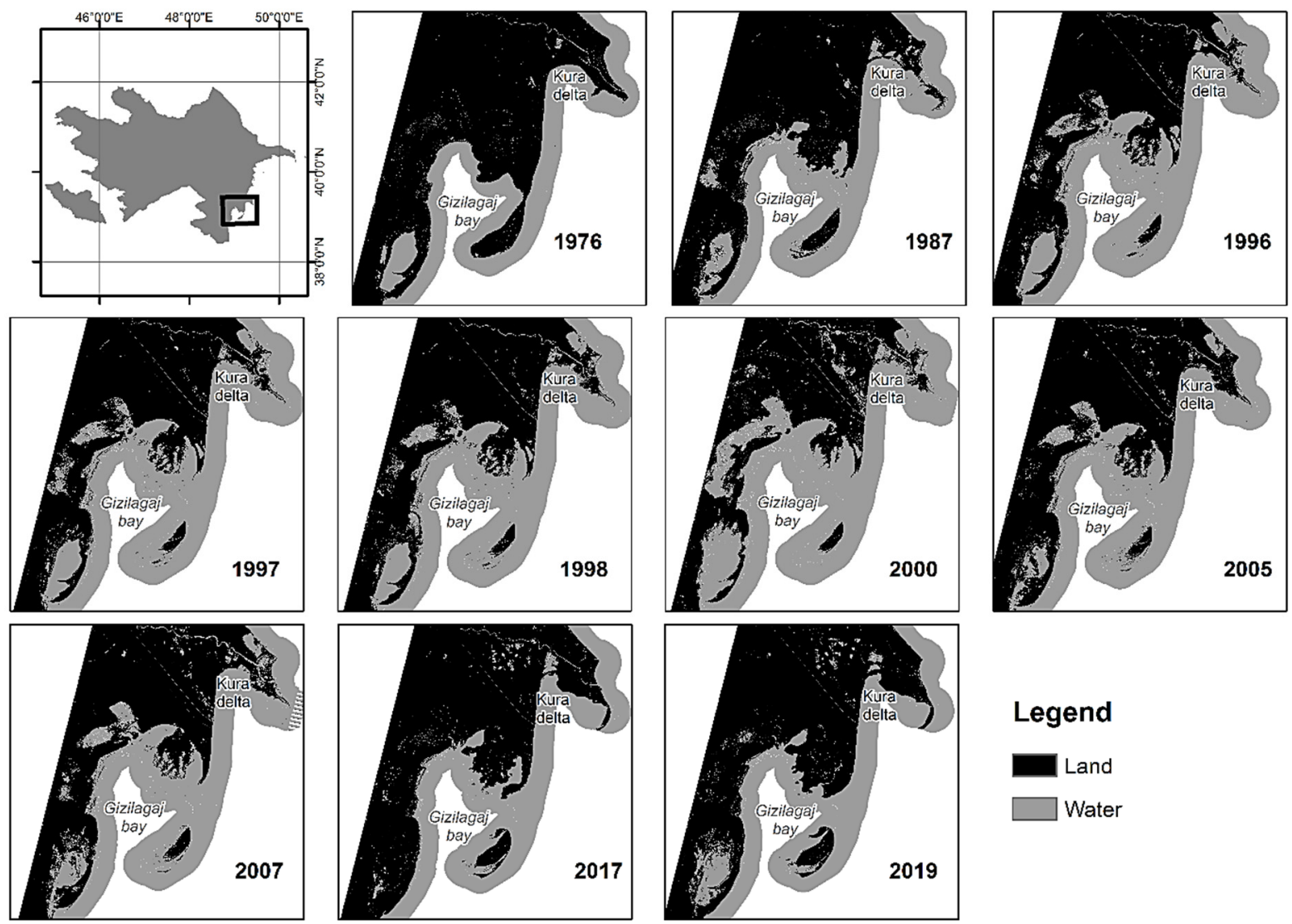

Fig. 6 Dynamics of the coasts of the Kura Delta and Gizilagaj Bay zone.
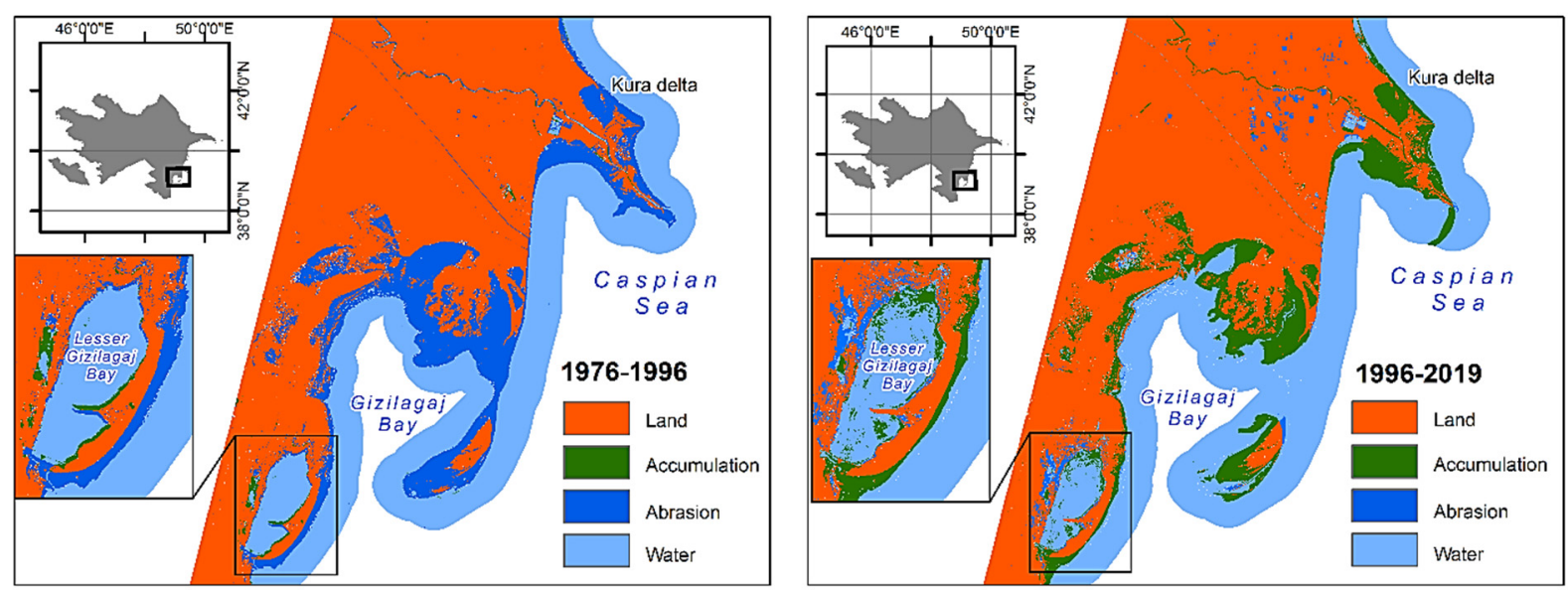

Fig. 7 Change detection of the coasts of the Kura Delta and Gizilagaj Bay zone.

2031 and 2041 is displaced normally, starting from the baseline at sea and intersecting the coastline (Shoreline) of 1976-2019; in our example, it is measured on a concrete vertical line. The quantities obtained because of the measurements, represent the projected displacements of the coastline of 2019 in 2031 and 2041.

In the Shirvan region (south-eastern Shirvan plain - Alat bay, Pirsaat bay, Shimal Goltug bay, Janub Goltug bay coasts), which has undergone hereditary tectonic subsidence and sedimentation processes mainly developed the abrasionaccumulative, alluvial, and alluvial-sea plains of accumulative areas, whereas in some places, the relief was complicated with eolian sand-shaped ridges, dunes, hills and ancient coastal uplands. The elevation and the cones of the mud volcanoes located in the place of anticlinal structures partially buried in the background of coastal plains washed away in regressive phases: Bahar on Alat Cape, Hamamdagh 


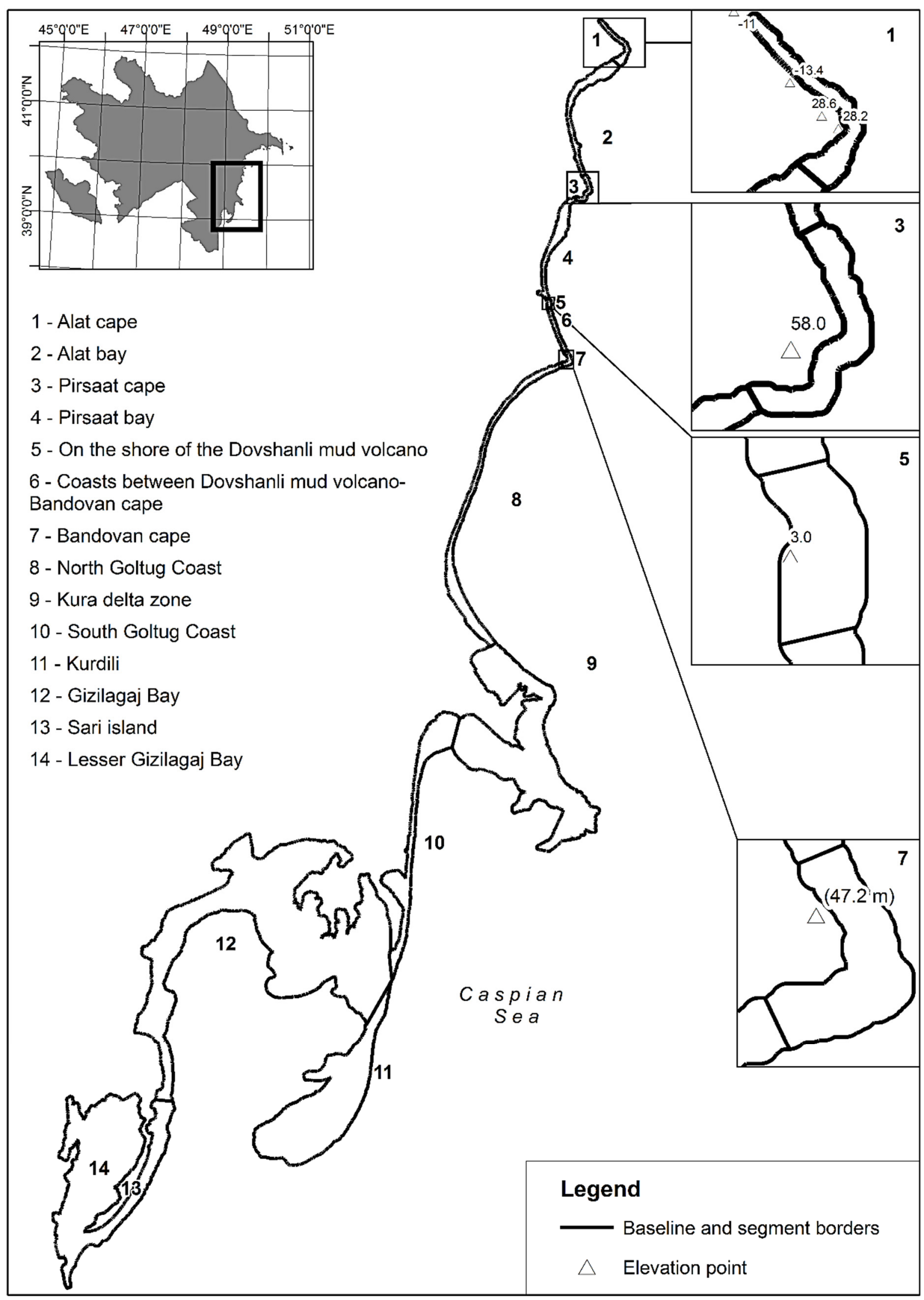

Fig. 8 Digital analysis of coastline of Kura sub-region for 1976-2019. 
Table 2 Statistical indicators on segments in Kura geomorphological sub-region.

\begin{tabular}{|c|c|c|c|c|c|c|c|c|c|}
\hline \multirow[t]{2}{*}{ Segments } & \multicolumn{2}{|c|}{ SCE* } & \multicolumn{3}{|c|}{$\mathrm{NSM}^{*}$} & \multicolumn{4}{|c|}{ EPR* } \\
\hline & Min & $\max$ & mean & $\min$ & $\max$ & mean & $\min$ & $\max$ & mean \\
\hline Alat cape & 36.52 & 819.34 & 192.62 & -260.24 & 90.08 & -41.65 & -6.09 & 2.11 & -0.97 \\
\hline Alat bay & 16.22 & 1243.24 & 375.34 & -807.54 & 151.25 & -87.45 & -18.88 & 3.54 & -2.04 \\
\hline Pirsaat cape & 16.39 & 407.01 & 99.02 & -135.32 & 147.59 & 33.57 & -3.16 & 3.45 & 0.78 \\
\hline Pirsaat bay & 40.71 & 1228.83 & 410.19 & -194.74 & 249.48 & 44.54 & -4.55 & 5.83 & 1.04 \\
\hline $\begin{array}{l}\text { On the coast of } \\
\text { the Dovshanli } \\
\text { mud volcano }\end{array}$ & 46.13 & 180.81 & 109.74 & 26.35 & 180.81 & 103.15 & 0.62 & 4.23 & 2.41 \\
\hline $\begin{array}{l}\text { Coasts between } \\
\text { Dovshanli mud } \\
\text { volcano- } \\
\text { Bandovan cape }\end{array}$ & 16.01 & 128.36 & 66.49 & -68.74 & 96.08 & 25.65 & -1.61 & 2.25 & 0.60 \\
\hline Bandovan cape & 20.77 & 244.42 & 123.66 & -85.99 & 222.16 & 108.99 & -2.01 & 5.19 & 2.63 \\
\hline $\begin{array}{l}\text { North Goltug } \\
\text { Coast }\end{array}$ & 32.71 & 1133.91 & 317.96 & -228.23 & 354 & 19.79 & -5.34 & 8.28 & 0.46 \\
\hline Kura delta region & 0 & 8823.42 & 2337.78 & -4664.48 & 4332.02 & -155.5 & -394.42 & 377.29 & -1.56 \\
\hline $\begin{array}{l}\text { South Goltug } \\
\text { Coast }\end{array}$ & 45.25 & 3412.38 & 603.25 & -1465.72 & 26.09 & -357.64 & -34.27 & 0.61 & -8.36 \\
\hline Kurdili & 107.22 & 18537.18 & 3567.95 & -17549.18 & 9357.44 & -875.52 & -889.72 & 218.81 & -38.20 \\
\hline Gizilagaj Bay & 358.02 & 9258.69 & 3704.94 & -9107.26 & 8272.03 & -659.54 & -334.51 & 193.43 & -17.00 \\
\hline Sari island & 4.31 & 2708.84 & 1023.29 & -967.37 & 1219.55 & -231.79 & -22.62 & 28.52 & -5.42 \\
\hline $\begin{array}{l}\text { Lesser Gizilagaj } \\
\text { Bay }\end{array}$ & 64.97 & 5783.93 & 2088.58 & -2897.79 & 4072.79 & 407.57 & -94.20 & 339.32 & 10.2 \\
\hline $\begin{array}{l}\text { Kura } \\
\text { geomorphological } \\
\text { subregion }\end{array}$ & 0 & 18537.18 & 1618.93 & -17549.18 & 9357.44 & -154.72 & -2470.6 & 4268.2 & -7.51 \\
\hline
\end{tabular}

* 1) SCE - Shoreline Change Envelope - The value of the largest change distance of a calculated coastline for all dates, 2) NSM - Net Shoreline Movement - net shoreline movement - final shoreline movement at the earliest and most recent dates, 3) EPR - End Point Rate - The final shoreline movement (NSM - Net Shoreline Movement) and its ratio to the recorded time interval.

on Pirsaat Cape, Dovshandag on Pirsaat Bay, mud volcano with the same name on Bandovan Cape. These mentioned geological structures (segments) are more intensively subjected to abrasion processes (Shirinov et al., 1998; Fig. 8).

The Kura deltas region consists entirely of accumulative coastal forms and corresponds to the Kura River delta, which began to form in the late 18th century and was formed because of the river's orientation to the east or the sea. The Kurdili segment, which belongs to the Kura delta region and has a complex genesis, corresponds to the underwater delta of the Kura River. It was formed owing to the accumulation of the Kura River and the combination of bars and small islands (Shirinov et al., 1998; Fig. 8).

Gizilaghaj region corresponds to the Gizilaghaj Bay which is the part of the Kura basin that has undergone the most tectonic subsidence processes in recent times. In the recent past, the paleo-Araz and Kura river or their separate tributaries, compensated for the tectonic subsidence and formed a flat and lowslope alluvial, alluvial-sea plain, their deposits and deltas. After the tributaries of the Kura and Araz river networks left this area, the amount of tectonic subsidence was not compensated by accumulation. This is the reason why the Gizilaghaj Bay began to form in this area. The formation and development of the Kurdili segment significantly weakened the bay's connection to the open sea and gave the coast its modern view. From 1929 onward, the sand islands with accumulative origin and bars located $50 \mathrm{~km}$ distance from Gizilaghaj Bay combined to form a vast land area (Sari Peninsula) due to falling sea levels, and divided the bay into two parts: The Great Gizilaghaj Bay and the Lesser Gizilaghaj Bay (Shirinov et al., 1998; Fig. 8).

Here we analyze some important segments. In the Alat cape (TransectID $=4609$ ) of Shirvan region, complicated by saline depressions, eolian relief forms (ridges, dunes, and hills), an ancient coastal swells of the New Caspian age (Shirinov, 1973), the calculated value of the largest variation of the coastline between 1976 and 2019 (SCE - Shoreline Change Envelope) was $159.21 \mathrm{~m}$. The final shoreline movement (NSM - Net Shoreline Movement) in 1976 and 2019 was $-97.3 \mathrm{~m}$ and its ratio to the recorded time interval (EPR - End Point Rate) was -2.28 , i.e. over time, the coastline receded $97.3 \mathrm{~m}$ because of washing. According to the forecast, the coastline in 2019 will be retreated at $45.59 \mathrm{~m}$, in 2031 and $51.88 \mathrm{~m}$, in 2041 because of possible washing and flooding processes (Fig. 9). 


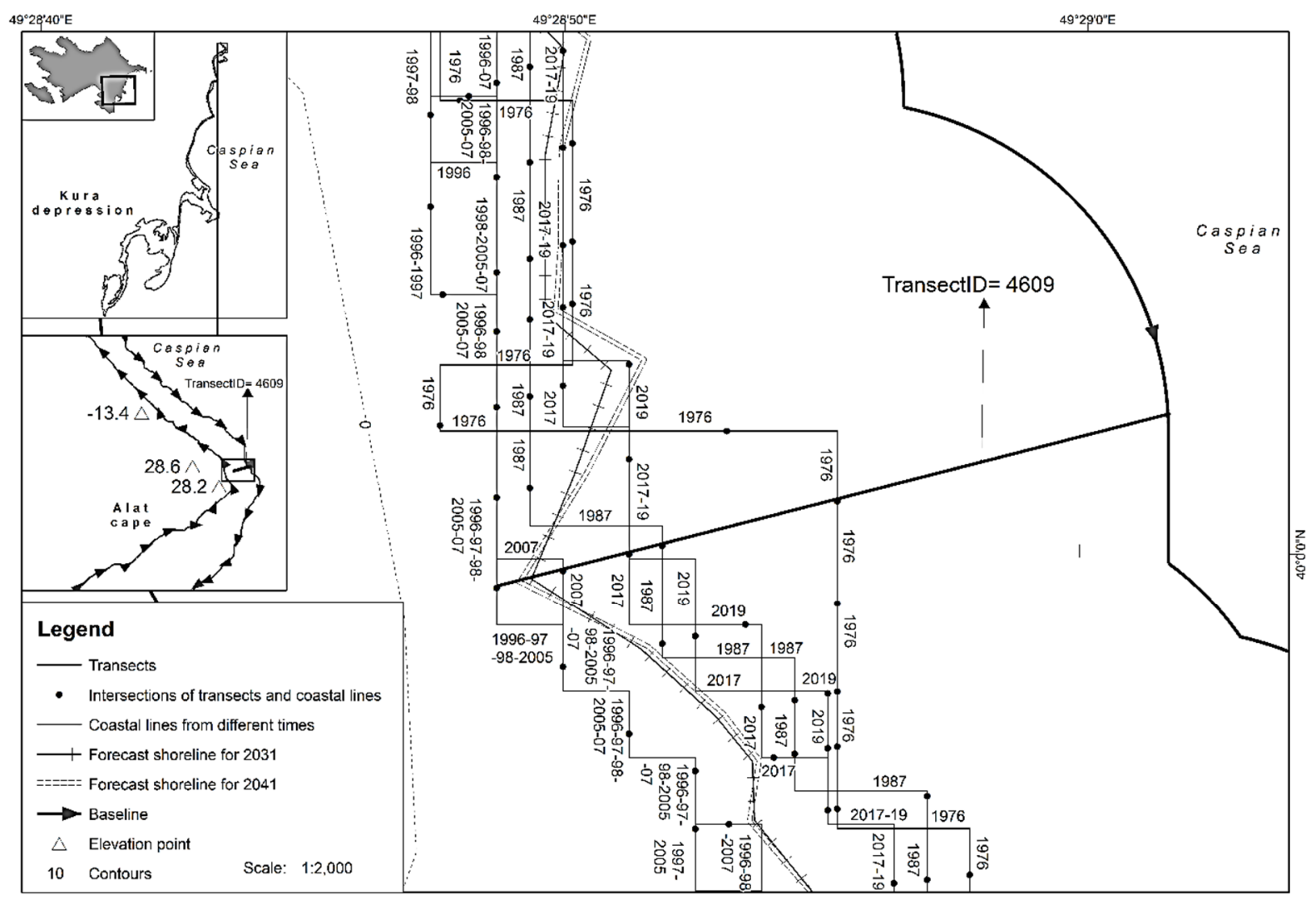

Fig. 9 Digital analysis of coastline on the coast of Alat cape for 1976-2019.

In the Pirsaat Cape (TransectID=5014), corresponding to the Hamamdag mud volcano, whose slopes are complicated by terraces of abrasionaccumulative origin (Shirinov, 1973), the value of the largest calculated change distance of the coastal line (SCE - Shoreline Change Envelope) was $163.31 \mathrm{~m}$; the final shoreline movement (NSM - Net Shoreline Movement) for 1976 and 2019 was $147.38 \mathrm{~m}$ and its ratio to the specified time interval (EPR - End Point Rate) was 3.45. That is, the coastline moved $147.38 \mathrm{~m}$ to the sea because of accumulation processes. According to the forecast, the coastline in 2019 will move towards the sea by $17.81 \mathrm{~m}$, in 2031 and $31.82 \mathrm{~m}$, in 2041 as a result of the expected accumulation processes (Fig. 10).

On the coasts of Bandovan Cape (TransectID = 5449), geologically complex with the mud volcano of the same name, corresponding to the rough anticline structure and the slopes are terraces, intensively fragmented (Shirinov, 1973) the estimated maximum shoreline change distance (SCE - Shoreline Change Envelope) in 1976-2019 was $244.42 \mathrm{~m}$; the final shoreline displacement (NSM - Net Shoreline Movement) for 1976 and 2019 was $213.31 \mathrm{~m}$ and it's the endpoint ratio (EPR) was 4.99. These values indicate the predominance of accumulation processes in the Bandovan Cape during this period. According to the forecast, the coastline in 2019 will move by $66.94 \mathrm{~m}$, in 2031 and $94.15 \mathrm{~m}$, in 2041 (Fig. 11).
In Kurdili sand bank (TransectID = 9993), which developed first as an island and then as a bar, with a complex genesis, the estimated value of the coastline change (SCE - Shoreline Change Envelope) during 1976-2019 was equal to $7828.8 \mathrm{~m}$. Because of the predominance of abrasion processes, the final shoreline movement (NSM - Net Shoreline Movement) for 1976 and 2019 was $-2668.81 \mathrm{~m}$ and its ratio to the specified time interval (EPR - End Point Rate) was -62.4. Based on the analysis, it was determined that $160.63 \mathrm{~m}$ will retreat in 2031 and $181.26 \mathrm{~m}$, in 2041 because of probable washing processes of the coastline in 2019 (Fig. 12).

In the Gizilagaj region (TransectID $=2427$ ), corresponding to the Gizilagaj Bay, which underwent the most tectonic subsidence processes in the Kura depression (Shirinov, 1973) the largest calculated distance of the coastline (SCE - Shoreline Change Envelope) during 1976-2019 was $2245.21 \mathrm{~m}$; the final shoreline displacement (NSM - Net Shoreline Movement) for 1976 and 2019 was $1474.18 \mathrm{~m}$ and its ratio to the specified time interval (EPR - End Point Rate) was 46.29. According to the forecast, the recent coastline will recede by $313.18 \mathrm{~m}$ in the next decade and $360.66 \mathrm{~m}$ in 20 years as a result of flooding and washing processes (Fig. 13). 


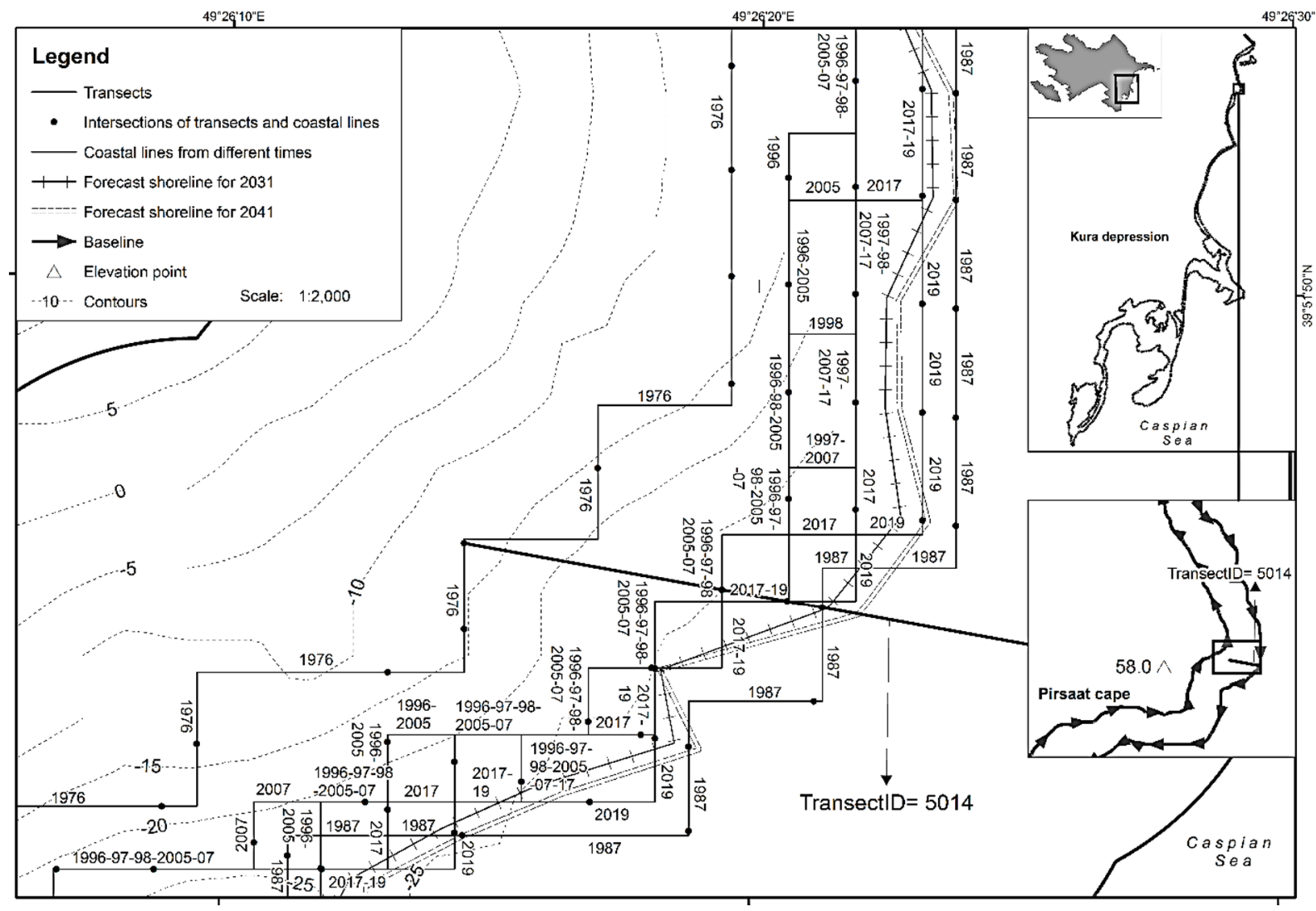

Fig. 10 Digital analysis of coastline on the shores of Pirsaat Cape for 1976-2019.

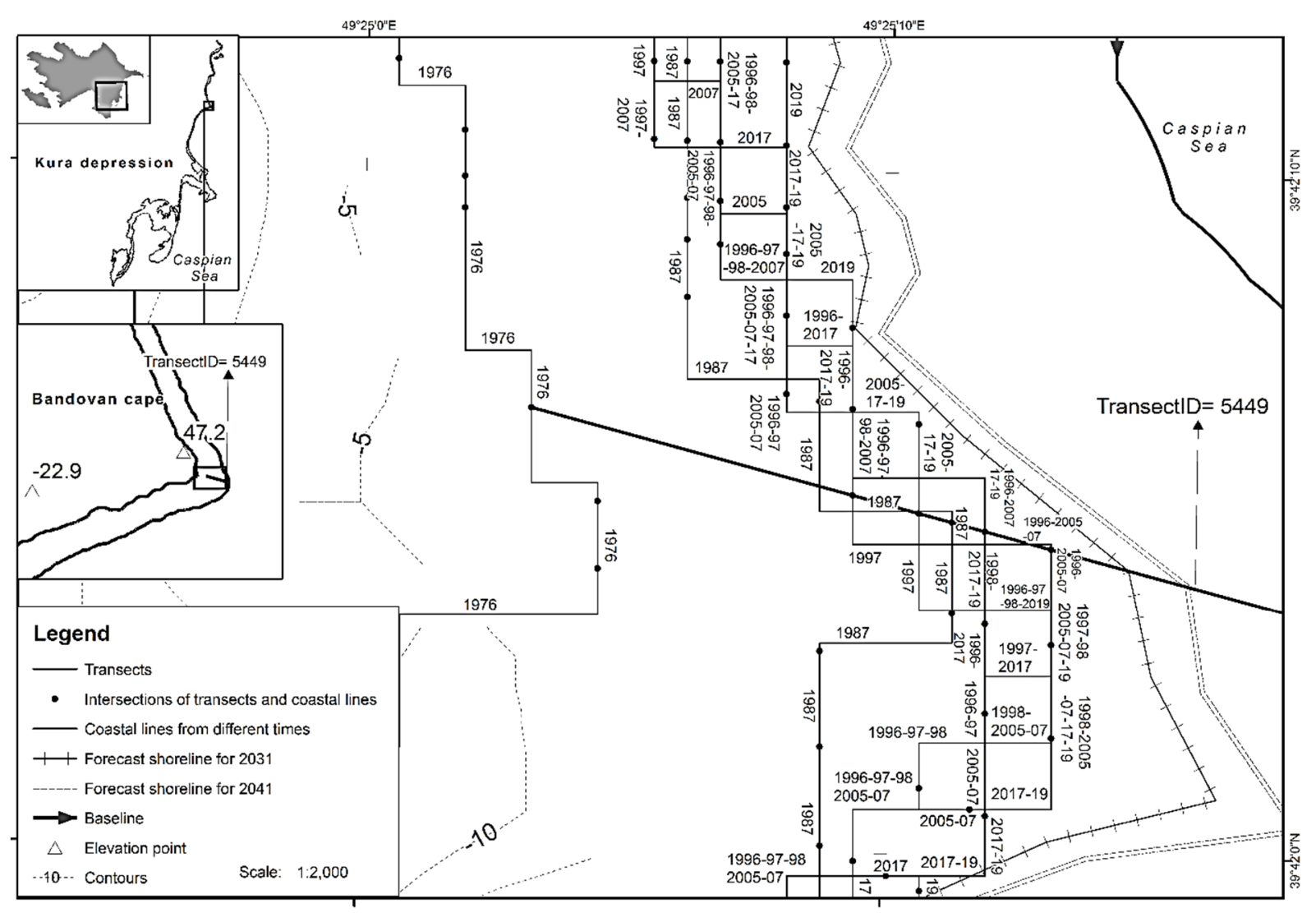

Fig. 11 Digital analysis of coastline on the coast of Bandovan cape for 1976-2019. 


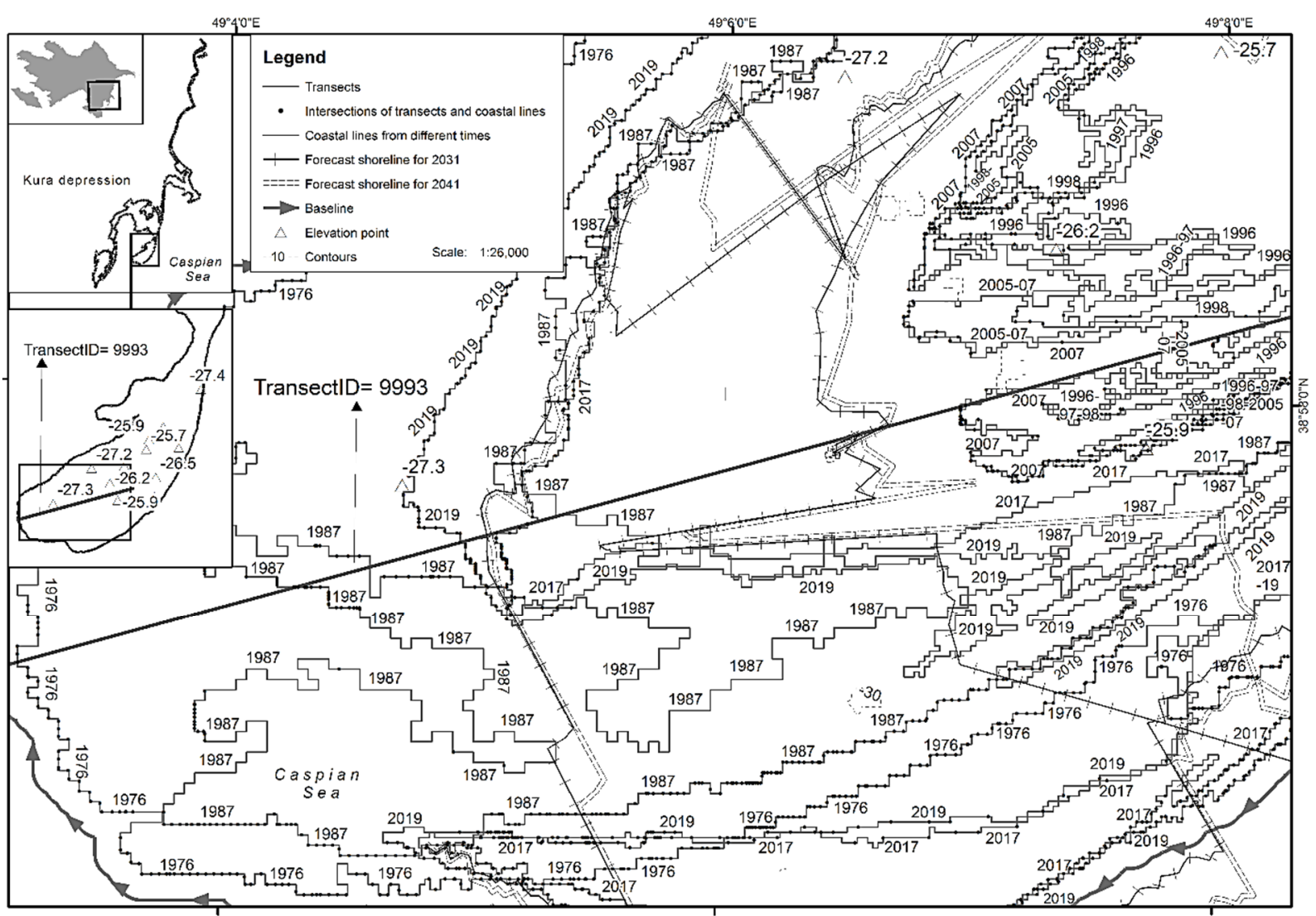

Fig. 12 Digital analysis of coastline on the Kurdili coast for 1976-2019.

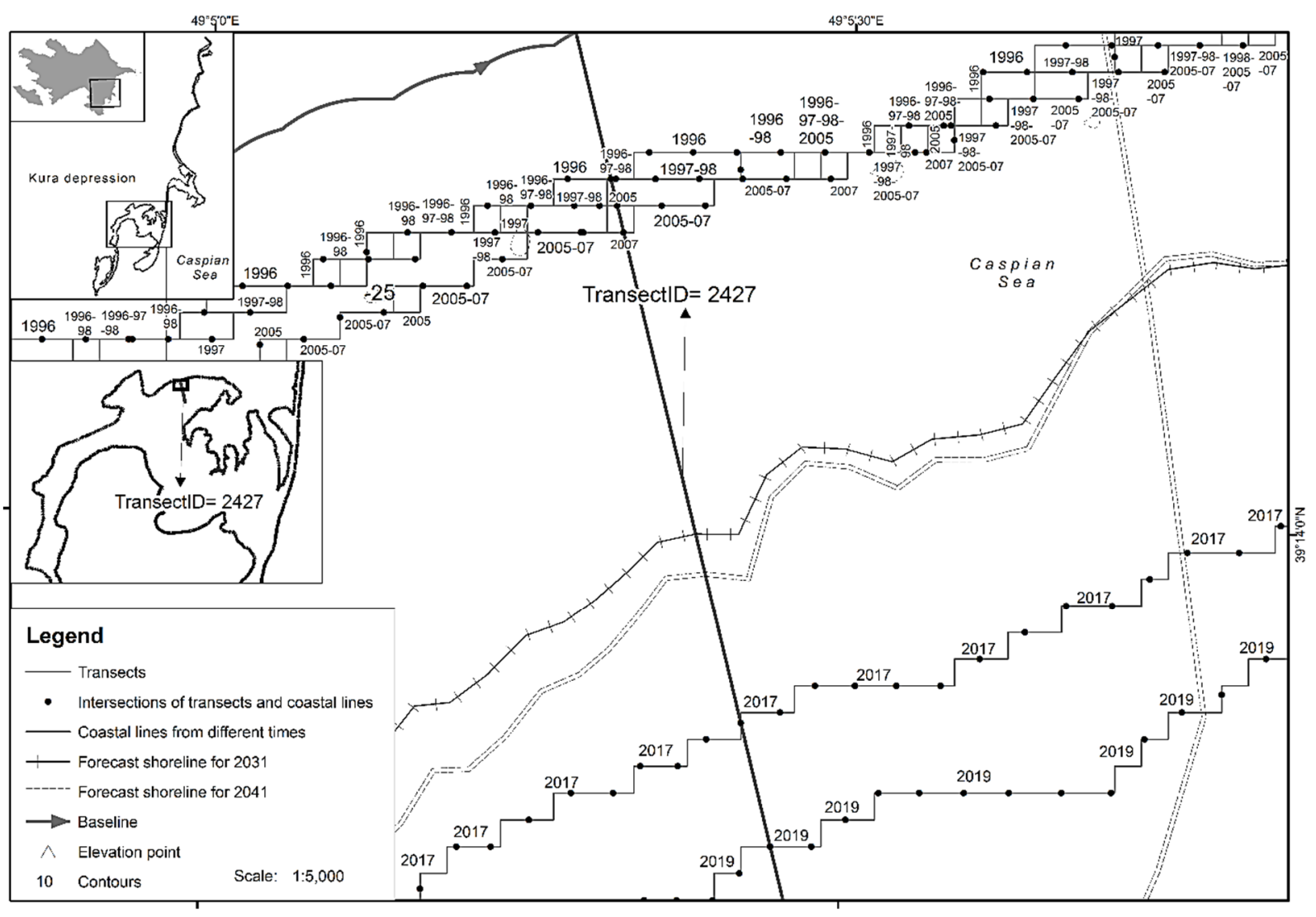

Fig. 13 Digital analysis of coastline on the coasts of Gizilagaj Bay for 1976-2019. 


\section{CONCLUSIONS}

The study found that the processes of abrasion (mainly due to flooding processes) and marine accumulation, developed in the Caspian zone, are closely interrelated with the level fluctuations of the Caspian Sea. The rise in the level of the Caspian Sea (1977-1996) contributed to the intensification of abrasion processes (correlation coefficient: 0.82 ), the weakening of accumulation processes. The stabilization and lowering of the sea level (19962019), caused the slowdown of flooding processes and the strengthening of accumulation processes (correlation coefficient: -0.46). According to the calculations, 402.854 sq. $\mathrm{km}$ of the area was flooded in 1976-1996 due to the rise of the Caspian Sea level $(2.43 \mathrm{~m})$ in the Kura geomorphological sub-region, while the area of accumulation processes was only $5.39 \mathrm{sq}$. km. During these periods, the average annual growth rate of abrasion (flooding) and accumulation processes was 20.143 sq. $\mathrm{km} /$ year and $0.27 \mathrm{sq} . \mathrm{km} /$ year, respectively. In the following period, the level of the Caspian Sea began to stabilize and decrease. As a result, most of the coastal areas of the sub-region, where intensive abrasion and flooding processes occurred, have been replaced by accumulative shores. During 1996-2019, due to the lowering of the Caspian Sea level $(1.39 \mathrm{~m})$, the land area increased by $305.678 \mathrm{sq}$. $\mathrm{km}$ due to accumulation processes. The area of abrasion and flooding processes was 22.562 sq. $\mathrm{km}$. During this period, the average annual growth rate of accumulation processes reached $13.29 \mathrm{sq} . \mathrm{km} /$ year, while the average annual growth rate of abrasion and flooding processes was $0.981 \mathrm{sq} . \mathrm{km} /$ year.

The study also measured the lengths of coastal lines in the Kura geomorphological sub-region based on raster mapping of water coefficients (NDWI) calculated by processing satellite images of different periods (1976-2019) and their vectorization. There is a close correlation between the length of the coastline and the processes of abrasion (washing) and accumulation, as well as the level of fluctuations of the Caspian Sea. Between 1976 and 1996, the length of the coastline increased from $467.583 \mathrm{~km}$ to $863,495 \mathrm{~km}(395.912 \mathrm{~km}, 54 \%)$. During that period, the washing area was 402,854 sq. $\mathrm{km}$, and the level of the Caspian Sea rose by $2.43 \mathrm{~m}$ (from $-28.93 \mathrm{~m}$ to $-26.5 \mathrm{~m}$ ). This is due to the increase in the indentation of the coastline under the influence of abrasion processes. During 1996-2019, the drop of the Caspian Sea level reached $1.39 \mathrm{~m}$ (from $-26.5 \mathrm{~m}$ to $-27.89 \mathrm{~m}$ ) and, as a result, the area of accumulation processes increased from 5.39 sq. $\mathrm{km}$ to $305.678 \mathrm{sq}$. km. This resulted in a simplification of the coastline configuration and a reduction in length from $863.495 \mathrm{~km}$ to $638.497 \mathrm{~km}(224.998 \mathrm{~km}, 26 \%)$.

Statistical indicators of coastlines for different periods (1976-2019) were calculated by using DSAS v.5 tools working on ArcGIS 10.8 platform in Kura geomorphological sub-region (value of the largest change of coastline distance for all dates, final coastal displacement on the earliest and most recent dates, final displacement of shorelines on early and recent dates and its ratio to the specified time interval, etc.) on 14 segments divided by zones and morphostructures of the sub-region (Alat cape, Alat bay, Pirsaat cape, Pirsaat bay, Dovshanli mud volcano, the area between Dovshanli mud volcano and Bandovan Cape, North Goltug Bay, Kura Delta zone, South Goltug Bay, Kurdili, Gizilagaj Bay, Sari Island, Lesser Gizilagaj Bay). Among the mentioned segments, on average, the maximum value of the maximum change distance of the coastline for all dates is in the Gizilagaj Bay zone (3704.94 m, average annual value: $2337.78 \mathrm{~m}$ ), and the largest value of the final coastal displacement on the earliest and most recent dates is in the Kurdili coast (-875.52 m, average annual value: $-38.2 \mathrm{~m}$ ).

During the study, the coastlines in the mentioned segments were forecasted for 10 and 20 years for 2031 and 2041, respectively. Here, the distance between the 2019 coastline and the coastlines for 2031 and 2041, obtained using the DSAS v. 5 tools, was calculated for the transects, vertical lines starting from the baseline at the sea and intersecting with the shorelines for 1976-2019, and in our example, it is measured on a concrete vertical line. As a result of abrasion (washing) processes expected in 2031 and 2041, coastline for 2019 Alat Cape will be retreated by 45.59 and $51.88 \mathrm{~m}$, in Alat Bay Coast by 149.85 and $181.97 \mathrm{~m}$, Dovshanli mud volcano and the coasts between the Bandovan Cape by 45.37 and $53.15 \mathrm{~m}$, the South Goltug Bay coast by 110.38 and $150.17 \mathrm{~m}$, the Kurdili coast by 160.63 and $181.26 \mathrm{~m}$, the Gizilagaj Bay coast by 313.18 and $360.66 \mathrm{~m}$, the coast of the Sari Island by 128.16 and $166.06 \mathrm{~m}$, respectively. As a result of possible accumulation processes, the coast of Pirsaat Cape will move to the sea by 17.81 and $31.82 \mathrm{~m}$, respectively, the coast of Dovshanli mud volcano will 46.31 and $69.52 \mathrm{~m}$, the coast of Bandovan Cape will 66.94 and $94.15 \mathrm{~m}$, the North Goltug Bay coast will move 253.84 and $512.21 \mathrm{~m}$ to the sea, respectively. In 2031, $289.83 \mathrm{~m}$ of Pirsaat Bay coast, $297.89 \mathrm{~m}$ of Kura delta coast, $432.91 \mathrm{~m}$ of Lesser Gizilagaj Bay coast will be withdrawn as a result of probable abrasion processes, and in 2041 as a result of probable accumulation processes; the 2031 coastline will move by $68.64 \mathrm{~m}, 69.56 \mathrm{~m}$ and $142.37 \mathrm{~m}$ to the sea in the mentioned segments, respectively.

\section{REFERENCES}

Alicandro, M., Baiocchi, V., Brigante, R. and Radicioni, F.: 2019, Automatic shoreline detection from eight-band VHR satellite imagery. J. Mar. Sci. Eng., 7, 459, 5366. DOI: $10.3390 /$ jmse 7120459

Appeaning, A.K., Walkden, M. and Mills, J.P.: 2008, Detection, measurement and prediction of shoreline recession in Accra, Ghana. ISPRS J. Photogramm. Remote Sens., 63, 5, 543-558. DOI: $10.1016 /$ j.isprsjprs.2008.04.001 
Aryastana, P., Ardantha, M. and Candrayana, K.W.: 2018, Coastline change analysis and erosion prediction using satellite images. MATEC Web of Conferences, 197, 13003. DOI: $10.1051 / \mathrm{matec}$ onf $/ 201819713003$

Aseev, A.A., Nikiforov, L.G., Simonov, Yu.G. and Timofeev, D.A.: 1988, Basic laws of geomorphology. Problemy teoreticheskoy geomorfologii, Simonov Yu.G., Timofeev, D.A., Ufimtsev, G.F. et al. (eds.). Moscow, Nauka, 90-111, (in Russian).

Ashis, K.P.: 2002, Coastal geomorphology and environment, P582, ACB Publs., Kolkata.

Dominici, D.: 2020, Remote sensing in coastline detection. J. Mar. Sci. Eng., 8, 7, 498, 1-2. DOI: $10.3390 /$ jmse 8070498

Fu, Y., Guo, Q., Wu X., Fang H. and Pan, Y.: 2017, Analysis and prediction of changes in Hashmi, M.D. and Ahmad, S.R.: 2018, GIS-based analysis and modeling of coastline erosion and accretion along the coast of Sindh Pakistan. J. Coast. Zone Manag., 21, 1. DOI: $10.4172 / 2473-3350.1000455$

Gasimov, J.Y.: 2014, Natural endo-exogenous factors affecting the ecogeomorphological conditions of the morphostructures of the Kur-Araz plain. Materials of the scientific-practical conference on Application directions of modern geography dedicated to the 90th anniversary of Prof. R.Kh. Piriyev, Baku: Baku University Publishing House, 550-555, (in Azeri).

Hashmi, M.D. and Ahmad, S.R.: 2018, GIS-based analysis and modeling of coastline erosion and accretion along the coast of Sindh Pakistan. J. Coast. Zone Manag., 21, 1. DOI: $10.4172 / 2473-3350.1000455$

Himmelstoss, E.A., Henderson, R.E., Kratzmann, M.G. and Farris, A.S.: 2018, Digital shoreline analysis system (DSAS) version 5.0 user guide. U.S. Geological Survey Open-File Report 2018-1179, 110 pp. DOI: $10.3133 /$ ofr20181179

Ignatov, Ye.I., Kaplin, P.A., Lukyanova, S.A. and Solovieva, G.D.: 1993, Evolution of the Caspian Sea coasts under conditions of sea-level rise: Model for coastal change under increasing "Greenhouse Effect". J. Coast. Res., 9, 1, 104-111.

Jackson, N.L., Nordstrom, K.F., Feagin, R.A. and Smith, W.K.: 2013, Coastal geomorphology and restoration. Geomorphology, 199, 1-7. DOI: 10.1016/j.geomorph.2013.06.027

Kalman, R.: 1960, A new approach to linear filtering and prediction problems. ASME J. Basic Eng., 82, 35-45. DOI: $10.1115 / 1.3662552$

Khalilov, H.A.: 2010, On the possibility of using the variability of the Caspian level. Works of the Azerbaijan Geographical Society, 5, 50-53, (in Azeri).

Khalilov, H.A.: 2020, The main factors of fluctuations in the level of the Caspian Sea. Geomorphology and environment (selected works). Baku, Europe, 414423, (in Azeri).

Komar, P.D.: 2010, Shoreline evolution and management of Hawke's Bay, New Zealand: Tectonics, coastal processes, and human impacts. J. Coast. Res., 26, 1, 143-156. DOI: $10.2112 / 08-1079.1$

Kroonenberg, S.: 2012, Rapid Caspian Sea level oscillations in the Holocene: synchronicity with global climate change. Quat. Int., 279-280, 257. DOI: 10.1016/j.quaint.2012.08.625

Leontiev, E.I. and Khalilov, A.I.: 1965, Natural conditions for the formation of the Caspian Sea shores. Baku, Izdatel'stvo Akademii nauk Azerbajdzanskoy SSR, 204 pp., (in Russian).
Liu, Y., Wang, X., Ling, F., Xu, Sh. and Wang, Ch.: 2017, Analysis of coastline extraction from Landsat-8 OLI Imagery. Water, 9, 816. DOI: 10.3390/w9110816

Long, J.W. and Plant, N.G.: 2012, Extended Kalman Filter framework for forecasting shoreline evolution. Geophys. Res. Lett., 39, 13, 1-6. DOI: $10.1029 / 2012$ GL052180

Mammadov, R.M.: 2007, Caspian Sea: Hydrometeorological variability and ecogeographical problems. Baku: Elm, 436 pp., (in Russian).

Mammadov, R.M.: 2014, Caspian Sea. Geography of the Republic of Azerbaijan: in 3 volumes, v.1, Physical geography. Baku: Europe, 275-291, (in Azeri).

Mammadov, R.M., Hadiyev, Y. and Kulizade, L.: 1998, Impact climate anomalies on the level of the Caspian Sea. The 2nd International Symposium on Climate and Water, Espoo. Finland, 972-980.

Mammadov, R.M. and Humbatov, A.I.: 1996, Long-term prognosis of the Caspian Sea-level. Regional Workshop on Coastal Zone Management, Chabahar. Islamic Republic Iran.

Mubarakm, M.: 2018, Coastline changes in North Bengkalis Island, Indonesia: satellite imagery analysis and observation. J. Degrade. Min. Land Manage, 5, 2, 1127-1132. DOI: $10.15243 / \mathrm{jdmlm} .2018 .052 .1127$

Nunes, M., Ferreira, O., Schaefer, M., Clifton, J., Baily, B., Moura, D. and Loureiro, C.: 2009, Hazard assessment in rock cliffs at Central Algarve (Portugal): A tool for coastal management. Ocean Coast. Manag., 52, 506515. DOI: 10.1016/j.ocecoaman.2009.08.004

Pugliano, G., Robustelli, U., Luccio, D.D., Mucerino, L., Benassai, G. and Montella, R.: 2019, Statistical deviations in shoreline detection obtained with direct and remote observations. J. Mar. Sci. Eng., 7, 137, 113-128. DOI: $10.3390 /$ jmse 7050137

Rio, L.D: 2009, Erosion risk assessment of active coastal cliffs in temperate environments. Geomorphology, 112, 82-95. DOI: 10.1016/j.geomorph.2009.05.009

Rychagov, G.I.: 1997, Holocene oscillations of the Caspian Sea, and forecasts based on palaeogeographical reconstructions. Quat. Int., 41-42, 167-172. DOI: $10.1016 / \mathrm{s} 1040-6182(96) 00049-3$

Sanchez, A.J., Lobo, F.J., Azor, A. and Barcenas, B.: 2010, Human-driven coastline changes in the Adra River deltaic system, southeast Spain. Geomorphology 119, 9-22. DOI: 10.1016/j.geomorph.2010.02.004.

Shirinov, N.Sh.: 1973, Geomorfologicheskoye stroyeniye Kuro-Araksinskoy depressii (Morfoskul'ptury), Baku: Elm, 215 pp., (in Russian).

Shirinov, N.Sh., Valiyev, H.A. and Aliyev, Y.G.: 1998, Nature and ecology of the Caspian Sea and its coasts, Baku: Elm, 1998, 190 pp., (in Azeri).

Svitoch, A.: 2012, Holocene transgressions of the Caspian Sea. Quaternary International, v. 279-280, 478-479. DOI: $10.1016 /$ j.quaint.2012.08.1616

Zollini, S., Alicandro, M., Gonzales, M.C., Dominici, V. and Buscema P.M.: 2020, Shoreline Extraction Based on an Active Connection Matrix (ACM) Image Enhancement Strategy. Journal of Marine Science and Engineering, 8, 9, 37-52. DOI: 10.3390/jmse8010009 